\title{
Trust, Coordination and Multi-level Arrangements: Lessons for a European Health Union
}

\author{
Martino MAGGETTI* ${ }^{*}$
}

\begin{abstract}
In the wake of the outbreak of the COVID-19 crisis, the Swedish and Swiss governments adopted a similar policy approach. They enacted mostly non-binding measures to contain the epidemic, relying on the high level of interpersonal trust and trust in political institutions that exist in both of these (broadly comparable) countries to ensure compliance. However, unlike Sweden's strategy, the Swiss policy response evolved during the early weeks of the "first wave", achieving public health and socioeconomic results that have been considered as satisfactory, notwithstanding the complex institutional setting and policy process, the central location of Switzerland in continental Europe, its openness and its closeness with deeply affected regions in Italy and France. To shed light on this policy response and to draw lessons from it, this paper firstly discusses the role played by the new Swiss Epidemics Act. This law centralises decision-making capacity at the federal level and expands the competences of the central government, while leaving leeway to subnational units for implementation and recognising the need for increased international regulatory cooperation. Secondly, it shows how such a solution - a multi-level arrangement steered from the federal level with quite strong vertical and horizontal coordination mechanisms - could work as a blueprint for a European Health Union.
\end{abstract}

\section{Policy Responses to THE PANDEMiC OUTBREAK}

"If it looks like you're overreacting, you're probably doing the right thing". ${ }^{1}$

"We wish to act as quickly as possible, but as slowly as necessary". ${ }^{2}$

The coronavirus disease 2019 (COVID-19) outbreak in early 2020 brought into being a major crisis, whose disruptive potential - in terms of public health, social, political, economic, psychological and cultural consequences - still needs to be fully delineated. Policymakers in charge of dealing with this crisis have been confronted

\footnotetext{
* University of Lausanne, Switzerland; email: martino.maggetti@unil.ch. This paper is an opinion piece based on personal research as well as on research in the framework of the project Trust in Governance and Regulation in Europe (TiGRE), funded by the European Union's Horizon 2020 research and innovation programme under grant agreement No. 870722.

1 Anthony S. Fauci, member of the US Coronavirus Taskforce, as reported in B Philipp, "The lesson of revised death toll estimates shouldn't be that distancing was an overreaction", The Washington Post, 9 April 2020.

2 Federal Councillor Alain Berset, press conference, 16 April 2020. (Original: "Nous souhaitons agir aussi vite que possible, mais aussi lentement que nécessaire".)
} 
with an extraordinary situation of Knightian uncertainty, whereby no solution was immediately available, risks were not predictable and existing knowledge was very limited. ${ }^{3}$ As COVID-19 poses an immediate threat to human health - it can be qualified as a "super wicked problem" that is not only extremely complex, but also particularly urgent. ${ }^{4}$ Against this background, the timing and the strictness of early policy responses, based on so-called non-pharmaceutical interventions, varied widely across countries (before eventually converging to some extent after a few months). ${ }^{5}$ These measures included reliance on merely informational policy instruments, the use of contact tracing applications, selective and targeted bans and social distancing, and prompt lockdowns and confinement policies with assorted coercive measures. ${ }^{6}$ Their variation depended on several factors, such as the perceived severity of the problem, experiences with previous crises and political and institutional capacity. ${ }^{7}$ Policy responses have not always been proportional to the extent of the threat; especially at the outset of the pandemic, policy under-reaction has frequently been observed. ${ }^{8}$

In that regard, the cases of Sweden and Switzerland are of particular interest, because both of their governments' strategies initially relied on informational and incentive measures to contain the spread of the disease. These measures mainly consisted of information campaigns on the voluntary application of hygiene and social distancing measures, which have been launched between mid to late February and early March 2020. Governments foresaw that compliance with these measures would be ensured by the high levels of interpersonal trust and trust in political institutions that (reportedly) exist in these countries (see Figure 1). ${ }^{9}$ This light-touch approach has

\footnotetext{
3 A Alemanno, "Taming COVID-19 by Regulation: An Opportunity for Self-Reflection" (2020) 11 European Journal of Risk Regulation 187.

4 K Levin et al, "Overcoming the tragedy of super wicked problems: constraining our future selves to ameliorate global climate change" (2012) 45 Policy Sciences 123.

5 S Flaxman et al, "Estimating the effects of non-pharmaceutical interventions on COVID-19 in Europe" (2020) 584 Nature 257.

6 T Hale et al, "Variation in government responses to COVID-19" (2020) 31 Blavatnik School of Government working paper.

7 G Capano et al, "Mobilizing Policy (in) Capacity to Fight COVID-19: Understanding Variations in State Responses" (2020) Policy and Society 1; D Toshkov, K Yesilkagit and B Carroll, "Government Capacity, Societal Trust or Party Preferences? What Accounts for the Variety of National Policy Responses to the COVID-19 Pandemic in Europe" (2020) Working paper, Institute of Public Administration, Faculty of Governance and Global Affairs, Leiden University, The Netherlands.

8 On policy disproportionality, see M Maor, "Policy overreaction" (2012) 32 Journal of Public Policy 231; M Maor, "Policy persistence, risk estimation and policy underreaction" (2014) 47 Policy Sciences 425; on under-reaction to COVID-19, see R Horton, The COVID-19 Catastrophe: What's Gone Wrong and How to Stop It Happening Again (Cambridge, Polity Press 2020).
}

9 As regards Sweden, see, for instance, the WHO meeting, WHO COVID-19 virtual press conference held on 29 April 2020, where Michael J. Ryan, Chief Executive Director of the WHO Emergencies Programme, reported that the Swedish government "really has trusted its own communities to implement that physical distancing", and the "Strategy in response to the COVID-19 pandemic" released by the Swedish Prime Minister's Office, stating that: "People in Sweden have a high level of trust in government agencies. This means that a large proportion of people follow government agencies' advice. In the current situation, people in Sweden are on the whole acting responsibly to reduce the spread of infection by, for example, restricting their social contacts". For Switzerland, see, for instance, the statement of Federal Councillor Alain Berset in "La Suisse a fait ses preuves", Le Temps, 13 June 2020: "In accordance with our democratic culture, the Federal Council has opted for collective intelligence and discernment. Forcing people to behave in a certain way does not work. You have to convince. This approach made it possible to avoid extreme measures at a time when other countries were restricting the freedoms of their citizens to a much greater extent. ... Mutual respect and trust between the Confederation and the cantons have always been perceptible", and the interview of the President of the Swiss Confederation, Simonetta Sommaruga, in Le Temps, 17 


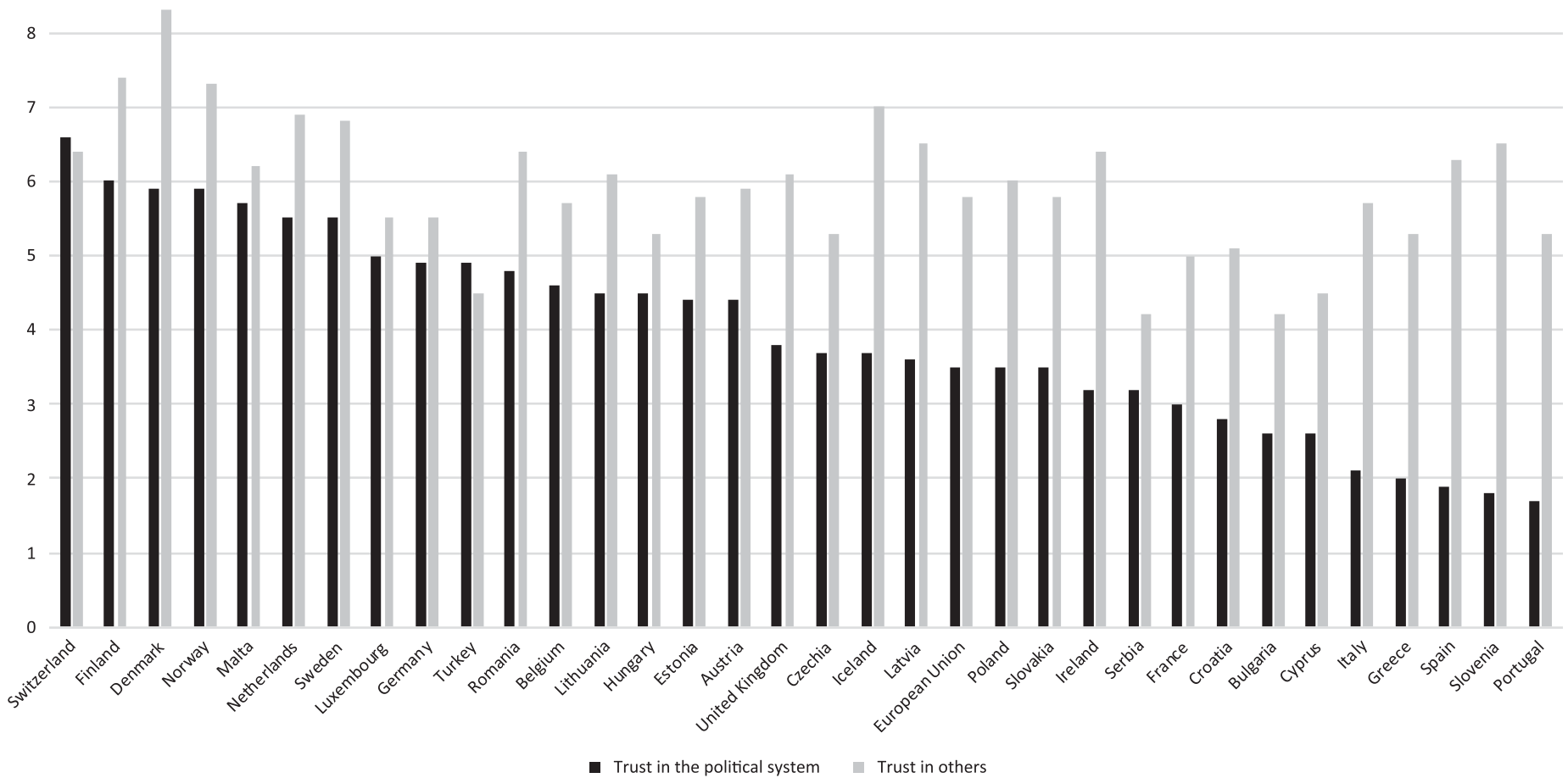

Figure 1. Trust in the political system and in others in European countries. Author's calculations based on Eurostat 2020 - Average rating of trust (Eurostat $4 \mathrm{~A} 2 \mathrm{Q} 3$ census data - 2013). 
been publicly defended by the top public officials in charge. In the wake of the outbreak, the Swedish Prime Minister Stefan Löfven said, "The only way to manage this crisis is to face it as a society, with everyone taking responsibility for themselves, for each other and for our country". ${ }^{10}$ Similarly, the Swiss Federal Councillor heading the Federal Office of Public Health (FOPH) Alain Berset said that "what counts is the support of the population [who] would not accept measures that are too harsh". ${ }^{11}$

In the follow-up, Swedish political authorities remained committed to their light-touch, highly technocratic approach. They continued to strongly rely on independent expert bodies, namely the Public Health Agency of Sweden (PHA) and the National Board of Health and Welfare (NBHW), not only for scientific advice, but also for making public policy decisions and for the operational management of the crisis. More stringent measures - such as gathering bans, limitations for bars and restaurants and restrictions to travel and to nursing home visits - have been introduced later and less extensively than in comparable countries, following a "mitigation" approach that lasted (at least) until summer 2020. ${ }^{12}$

Such a containment strategy - with all of the limitations of an early assessment of such a complex phenomenon, which can only be very tentative - has been considered as inadequate, as it came along with one of the highest per capita percentages of confirmed cases in the world and with high mortality rates, especially among elderly people in retirement homes and among immigrant communities. In particular, when compared to Switzerland or to other Scandinavian countries, Sweden's COVID-19related excess mortality in the period under consideration has been 2.5 higher and, respectively, almost 10 times higher. ${ }^{13}$ At the same time, neither the economic performance of Sweden surpassed that of the abovementioned countries (in the second quarter of 2020, GDP growth has been -8.3 in Sweden, compared to -8.2 in Switzerland, -6.9 in Denmark, -4.4 in Finland and -5.1 in Norway), ${ }^{14}$ nor has "herd immunity" been more effectively achieved than elsewhere. ${ }^{15}$

A number of factors explaining these shortcomings can be (provisionally) mentioned: a deferential attitude of policymakers towards experts with an institutionalised monopoly of expertise; experts who, in turn, were overconfident in their early opinions on the pandemic that proved erroneous (eg in their view about the role of asymptomatic carriers in spreading the disease); excessive reliance on soft coordination among

April 2020, where she said: "We need to restore people's confidence, while avoiding a rebound in the epidemic. ... Asking people to wear a mask outside at all times? It doesn't work here.” (Translations from French are mine.)

10 Quoted in N Rothschild, "Sweden Is Open for Business During Its Coronavirus Outbreak", Foreign Policy, 24 March 2020.

11 Press conference of the Swiss Federal Council, 20 March 2020.

12 J Ludvigsson, "The first eight months of Sweden's COVID-19 strategy and the key actions and actors that were involved" (2020) forthcoming in Acta Paediatrica; see also R Milne, "Swedish expert admits country should have had tighter coronavirus controls", Financial Times, 3 June 2020.

13 Author's calculations based on M Roser et al, "Coronavirus Pandemic (COVID-19)" (2020), Published online at OurWorldInData.org < https://ourworldindata.org/coronavirus> (last accessed 5 July 2020); MJ Conyon, L He and S Thomsen, "Lockdowns and COVID-19 Deaths in Scandinavia" (2020), available at SSRN 3616969.

14 Data come from OECD.stat, Quarterly National Accounts: "Quarterly growth rates of real GDP, change over previous quarter".

15 EJW Orlowski and DJA Goldsmith, "Four months into the COVID-19 pandemic, Sweden's prized herd immunity is nowhere in sight" (2020) 113 Journal of the Royal Society of Medicine 8. 
agencies, regions and local authorities that appeared to be inappropriate in times of crises; and the poor performance of local authorities in charge of the decentralised healthcare system - in a context of defunding of elder care and decentralisation of public health oversight. $^{16}$

Instead, after an initial period of underestimation of the seriousness of the crisis, Swiss political authorities have updated their prior beliefs and progressively revised their approach in accordance with new relevant information. This information included the alarms triggered by Swiss epidemiologists and medical scientists, who, along with developing epidemiological models and scenarios, wrote two influential open letters to the federal government, offered interviews in the news media and published their standpoints on social media. ${ }^{17}$ Evidence regarding the impact of the pandemic coming from Italy and the first cantons where COVID-19 cases were found has also been factored into the decision-making process. ${ }^{18}$ As a result, the political steering of the Swiss strategy has been reinforced. ${ }^{19}$

Accordingly, the Swiss government enacted a step-by-step moderate interventionism in a way that has been considered as "consistent and ultimately quite effective", ${ }^{20}$ at least until the immediate aftermath of the period that has been called "the first wave" (early July 2020 at the time of writing). ${ }^{21}$ First of all, the Swiss government organised broad consultations with cantons and between administrative offices that were mainly orchestrated the Swiss FOPH. Then, on 28 February, the government enacted a first ordinance on measures to combat the coronavirus in the context of a "special situation" as defined by the Federal Epidemics Act (EpidA) (see next section), including a ban of events with more than 1000 participants. On 16 March, an "extraordinary situation" was declared. As a consequence, competencies have been centralised at the federal level, and a new ordinance has been issued that prohibits all private and public events, closed restaurants, markets and all places of entertainment

\footnotetext{
16 J Pierre, "Nudges against pandemics: Sweden's COVID-19 containment strategy in perspective" (2020) 39 Policy and Society 478; KJ Karlsson, "Sweden's Failure to Protect Its Elderly Population from Coronavirus Started Long before the Pandemic", Foreign Policy, 23 June 2020.

17 See notably: the letter entitled "Gefärlichkeit von COVID-19" addressed to Federal Councillor Alain Berset on 25 February 2020 by Christian Althaus and three other professors, and the letter entitled "Offener Brief an den Bundesrat bzgl. Coronavirus" addressed to the Federal Council on 12 March 2020 by Christian Althaus and twenty-three other scientists.

18 Eidgenössisches Departement des Innern EDI, Bundesamt für Gesundheit BAG, "Taskforce 2019-nCoV Protokoll”, Bern, 23 January 2020; Eidgenössisches Departement für Verteidigung, Bevölkerungsschutz und Sport VBS, Bundesamt für Bevölkerungsschutz BABS, Geschäftsstelle BSTB, "Protokoll der a.o. Direktorenkonferenz BSTB vom 24.01.2020 (Informationsveranstaltung)”, Bern, 27 January 2020; Eidgenössisches Departement des Innern. Krisenstab des Bundesrats Corona (KSBC), "1. Sitzung: Kick-off Krisenstab des Bundesrats Corona (KSBC)”, Bern, 25 March 2020.

19 Epitomising - somewhat paradoxically - the primacy of politics.

20 As mentioned by L Wolf, "Les sciences à l'épreuve de la pandémie Dans le processus décisionnel de gestion de la crise liée au Covid-19, quid du rôle des scientifiques?” Domaine Public, 1 July $2020<$ https://www.domainepublic.ch/ articles/36976>. In that regard, see in particular: C Althaus, "Real-time modeling and projections of the COVID-19 epidemic in Switzerland" (2020) < https://ispmberngithubio/covid-19/swiss-epidemic-model/>; P Karnakov et al, "Data driven inference of the reproduction number (R0) for COVID-19 before and after interventions for 51 European countries" (2020) 150 Swiss Medical Weekly 20313; JC Lemaitre et al, "Assessing the impact of nonpharmaceutical interventions on SARS-CoV-2 transmission in Switzerland" (2020) 150 Swiss Medical Weekly 20395; C Althaus et al, "Time is of the essence: containment of the SARS-CoV-2 epidemic in Switzerland from February to May 2020", preprint available at <https://www.medrxiv.org/content/10.1101/2020.07.21.20158014v1>.

21 Cellule enquête Tamedia, La première vague (Geneva, Éd. Slatkine 2020).
} 
such as museums, libraries and cinemas. Schools, universities and businesses where sufficient social distancing cannot be maintained have also been affected. A complete lockdown and mandatory confinement of the population has, however, been avoided. On 31 March, a scientific advisory board was appointed by the federal authorities.

The Swiss policy response to the COVID-19 crisis - based on a series of rapid, smallscale adaptations - can be qualified as flexible, experimentalist and orientated towards policy learning. ${ }^{22}$ On the one hand, initial reliance on informational and incentive measures has been transformed into the application of harder rules. On the other hand, the large room for manoeuvre traditionally granted to cantonal governments has been provisionally revoked. These adaptations are worthy of attention, as they departed from the policy paradigm under which Swiss policymakers usually work: that is, selective and only subsidiary federal intervention, combined with strong cantonal autonomy - in particular with regards to public health - within a highly decentralised federal system. ${ }^{23}$ The timing of this response is also remarkable, as the Swiss policy process is usually considered as slow, reactive, complex and incapable of rapid adaptations; moreover, the response has been largely consensus-based, albeit in the current context of (relative) polarisation. ${ }^{24}$

This piece suggests that multi-level coordination devices have been crucial to achieving these results. The next section examines the institutional conditions underpinning the Swiss strategy from the perspective of vertical and horizontal coordination. It also mentions some existing drawbacks and uncertainties. Section III draws some lessons for a European Health Union.

\section{Coordination and multi-level arrangements in Switzerland}

Political leadership is necessary but insufficient to ensure the political management of a crisis. A "consistent and ultimately quite effective" policy response - such as the one offered by the Swiss government so far - is grounded in underlying institutional conditions facilitating such a response. In the Swiss case, these conditions correspond to a multi-level setting with quite strong coordination tools that allows for local experimentation and guarantees democratic legitimacy while ensuring political steering capacity and the adoption of a system-wide approach. ${ }^{25}$ This section reviews and discusses these coordination tools. On the one hand, (1) the legal and politicaladministrative instruments made available by the new federal act on the control of communicable human diseases (EpidA), in force since 2016, allowed federal

\footnotetext{
22 M Maggetti and P Trein, "Multilevel governance and problem-solving: Towards a dynamic theory of multilevel policy-making?" 97 Public Administration 355.

23 W Linder, Swiss Democracy: Possible Solutions to Conflict in Multicultural Societies (Basingstoke, Palgrave MacMillan 2010).

24 P Sciarini, M Fischer and D Traber, Political Decision-Making in Switzerland: The Consensus Model under Pressure (Basingstoke, Palgrave MacMillan 2015); Y Papadopoulos and M Maggetti, "Policy Style(s) in Switzerland. Under Stress" in M Howlett and J Tosun (eds), Policy Styles and Policy-Making: Exploring the Linkages (Abingdon, Routledge 2018).

25 The Norwegian approach was comparable in that regard, even if the contextual conditions were quite different. See T Christensen and P Lægreid, "Balancing governance capacity and legitimacy-how the Norwegian government handled the COVID-19 crisis as a high performer" (2020) 80(5) Public Administration Review 774.
} 
authorities to centralise competences in a critical juncture of the pandemic crisis. On the other hand, (2) institutionalised cooperation with and among Swiss cantons has been instrumental in overcoming some of the discrepancies and in pushing for more effective policy measures, namely through the Swiss Conference of the Cantonal Ministers of Public Health (GDK-CDS). To conclude, (3) some shortcomings of the current system are identified, referring to ambiguities, contradictions and loopholes in the Swiss policy response. More broadly, the ambivalent role of "trust" in the political management of the crisis is discussed.

(1) Contrary to many countries, Swiss political authorities could rely on an existing legal framework for governing the pandemic: that is, the new EpidA. The main pillars of this piece of legislation include measures to make the population aware of their individual responsibility, the disentanglement of federal and cantonal powers, the strengthening of the leading role of the federal state, the reinforcement of the legality of control measures and the conformity of Swiss law with international regulations, first and foremost the international health regulations adopted under the framework of the World Health Organization (WHO). ${ }^{26}$ The EpidA concretely provides informational and incentive measures, along with coercive measures directed towards individuals (eg their quarantine and isolation) and towards the general public or specific groups (eg the banning of public or private events and the closure of schools and other public institutions or private companies), as well as measures concerning borders controls and the international transport of persons.

A three-step model is established by the EpidA, which, depending on the severity of the situation, proceeds to a progressive centralisation of the competence to take action in the hands of the federal government and to an expansion of the range of measures that can be adopted. ${ }^{27}$ In the field of public health, the federal government has only partial competence, with the cantons being generally in charge. ${ }^{28}$ As regards public information and prevention, the EpidA establishes a joint competence to the FOPH and the cantons, with an obligation of coordination. ${ }^{29}$ When the situation is considered to be normal, the cantons are competent to take the necessary measures aimed at both individuals and the population. A special situation is declared when a serious risk to public health that cannot be successfully managed at the cantonal level exists or when the WHO has determined the presence of a health emergency of international scope threatening the health of the population in Switzerland. In an extraordinary situation (which is not explicitly defined in the EpidA), the federal government has ample room for manoeuvre to order any necessary action for all or part of the country through emergency ordinances, without the need to rely on a further legal basis.

As outlined in the previous section, this legal framework allowed for a fine-grained management of the crisis. Federal authorities were able to react relatively quickly and

\footnotetext{
26 F Bernard, "La loi sur les épidémies à l'épreuve du nouveau coronavirus" (2020) 30 Jusletter 1.

27 F Bernard, "La répartition des compétences entre la Confédération et les cantons en situation de pandémie" (2020) Revue de droit suisse 55 .

28 See G Biaggini. BV Kommentar: Bundesverfassung der Schweizerischen Eidgenossenschaft (Zurich, Orell Füssli 2017), namely BV 118 N 15.

29 EpidA, Art 9.4.
} 
quite proportionally to the development and evolution of the pandemic. The declaration of an extraordinary situation also had a powerful symbolic impact on both the public perception of the seriousness of the crisis and on the perceived responsiveness of the federal government. Importantly, the availability of policy instruments has been complemented by the existence of a transversal administrative coordination device consisting of the Corona Task Force of the FOPH created in late January, the Federal Staff for Civil Protection from early March and, finally, the Federal Council's Corona Crisis Staff, which was set up on 20 March. ${ }^{30}$ The latter has been pivotal for the management of the pandemic. Mainly focusing on the coordination of crisis management and dealing with the impact of the crisis on the health system, it has brought together representatives from the cantons, all federal departments and the Federal Staff for Civil Protection. Members of the scientific community (especially from the Swiss National COVID-19 Science Task Force), civil society and business have also participated regularly in its meetings. The Secretary General of the Conference of Cantonal Governments helped to coordinate work with the cantons, an important aspect of the "extraordinary situation" within the scope of Article 7 of the EpidA.

(2) A decentralised system of governance involves higher transaction costs and may create incoherencies in the local application of rules. However, it also offers some distinct advantages for the management of a crisis. Cantons work as policy laboratory where solutions are experimented with and tested on the ground; ${ }^{31}$ federalism also facilitates the application of tailor-made policies that are adapted to each specific local situation (eg stricter bans in the cantons most affected by the pandemic). ${ }^{32}$ At the same time, coordination devices are crucial to ensuring policy coherence and uniform nationwide implementation. In the management of the pandemic, inter-cantonal conferences have been instrumental not only in supporting the homogeneous implementation of the rules, but also in legitimising the progressive centralisation of competencies that has been enacted under the EpidA. For instance, the Swiss Conference of the Cantonal Ministers of Public Health promulgated a document on the criteria for the implementation of public events bans, ${ }^{33}$ provided support and offered horizontal and vertical coordination instruments to federal decisions such as those regarding school closures $^{34}$ and supported supra-regional measures to ensure that the cantons coordinate their actions as far as possible (eg regarding the obligation of wearing masks on public transport). ${ }^{35}$

\footnotetext{
30 Eidgenössisches Departement des Innern. Krisenstab des Bundesrats Corona KSBC, "Rapport final: Etat-major du Conseil fédéral chargé de gérer la crise du coronavirus (EMCC)", Bern, 19 June 2020.

31 K Füglister, Cantons as Policy Laboratories of the Federal State? The Diffusion of Health Insurance Subsidy Policies among the Swiss Cantons within a Federal State (Zurich, University of Zurich 2011).

32 Y Willi et al, "Responding to the COVID-19 Crisis: Transformative Governance in Switzerland" (2020) 111(3) Tijdschrift voor economische en sociale geografie 302.

33 Swiss Conference of the Cantonal Ministers of Public Health (GDK-CDS), "Nouveau coronavirus. Critères d'application de l'interdiction de manifestations", press release, 5 March 2020.

34 Swiss Conference of the Cantonal Ministers of Public Health (GDK-CDS), "Nouveau coronavirus: Les directrices et directeurs cantonaux de la santé adhèrent à la décision du Conseil fédéral”, press release, 13 March 2020.

35 Swiss Conference of the Cantonal Ministers of Public Health (GDK-CDS), "Nouveau coronavirus: Obligation du port du masque dans les transports publics: une mesure au niveau national”, press release, 1 July 2020.
} 
(3) The Swiss approach has been criticised in the news media and elsewhere for entailing some hesitations, fumbling, back and forth, legal uncertainty and discrepancies in the application of the rules - experimentalism comes indeed at the expense of linearity. This incremental and experimentalist approach has been defended by public authorities through the need to secure citizens' support by avoiding the implementation of harsh measures too abruptly. ${ }^{36}$ However, it became clear that awareness-raising campaigns do not work alone to curb the spread of the disease, so that it was necessary to resort to coercive measures by adopting legal acts accompanied by sanctions. ${ }^{37}$ While existing social trust was initially expected to avoid these coercive measures, individual solutions were in fact largely insufficient, and cantonal policies needed to be coordinated in order to be effective. As an illustration, whilst the government issued guidelines recommending the use of masks on public transport, the percentage of people voluntarily complying with this piece of advice was as low as $17 \%$ before the introduction of the obligation. ${ }^{38}$ After a hard rule had been introduced, most people complied with it even if monitoring and sanctioning was only loosely enforced. ${ }^{39}$ What mattered was the normativity of such rules.

This is not to say that coercive measures should be unconditionally preferred over noncoercive ones; quite to the contrary, the latter are useful, and probably also necessary, to increase the effectiveness of the former. Policymakers should therefore carefully craft and rapidly fine-tune - an appropriate policy mix involving both soft and hard interventions. In doing so, relying on interpersonal and political trust is important, as much as is nurturing a certain amount of functional distrust that allows citizens and stakeholders to keep policymakers accountable and trigger alarms when needed.

All in all, however, a long-term assessment of this strategy is still pending. Further research should examine the impact of the re-cantonalisation of competencies in Switzerland and the progressive de-confinement measures that have been introduced after the first wave, whose timing - affected by the pressures exerted by some political parties and economic interest groups - has been considered as probably "premature" by the COVID-19 scientific task force. ${ }^{40}$

\section{Lessons for an EU Health Union}

Mutatis mutandis, the Swiss case provides three lessons to the EU, whereby primary responsibility for public health and for healthcare systems lies with the Member States.

(1) An EU European Health Response Mechanism as proposed by the European Parliament (EP) would be helpful. ${ }^{41}$ Such a mechanism should, however, include not

36 Press conference of the Swiss Federal Council, 20 March 2020.

37 Bernard, supra, note 27.

38 24heures, "L'obligation de porter un masque convainc", 30 April 2020.

39 RTS Info, "La grande majorité des Suisses portaient un masque lundi dans les transports publics", 7 July 2020.

40 See, for instance, Economiesuisse, "Surmonter le choc du COVID: mesures pour favoriser une reprise rapide de l'économie", press release, 30 April 2020; A Niederer, "Die Corona-Fallzahlen nehmen wieder leicht zu”, Neue Zürcher Zeitung, 17 June 2020.

41 European Parliament, "Parliament wants a European Health Union”, press release, 10 July 2020. 
only operational measures, but also a streamlining of decision-making procedures. A progressive, temporary, partial centralisation of political authority can be contemplated, in line with the Swiss three-step model. As a safeguard, accountability towards the EP should be reinforced.

(2) The governance of health policy is an extreme instance of multi-levelness, as it involves cooperation among international bodies such as the WHO, EU agencies, national governments and the local level, which has a crucial role in implementation. Besides reinforcing EU agencies - the European Centre for Disease Prevention and Control (ECDC) and the European Medicines Agency (EMA) - it is essential to strengthen horizontal coordination mechanisms among EU institutions and agencies, as well as vertical coordination across levels of governance. Such coordination tools can take the form of task-specific networked organisations and dedicated task forces.

(3) Governments can hardly rely on trust-based measures only or foremost, even in high-trust societies. Trust is important to ensure smooth compliance with hard rules, as it increases the normativity of coercive measures. Nevertheless, information, incentives and nudges alone appear insufficient to manage a large-scale crisis. As the case of Sweden has shown, excessive trust - deference to an agency claiming an institutionalised monopoly of expertise on the matter - can even have counterproductive effects. 